\title{
A Century of Rural Change in Northeastern Transylvania: Corbu and its Region
}

\author{
Muica, N.* $\mathcal{E}$ Turnock, D.**
}

\begin{abstract}
This is a study of a rural commune in the northeast of Transylvania which has attracted geographical on several occasions during the last century in such a way as to provide in-depth perspectives on the progress of development in the context of a frontier region at the contact of Hungarian and Romanian settlement. Although private farming has persisted without the upheaval of collectivisation, the area has been marginalised and continues to lose population with only limited prospects for diversification. But the community is both stable and sustainable and, lying at the centre of a scattered Romanian population in the Bistricioara Valley, could expand its cultural role into light industry to complement the tourism in the nearby Hungarian town of Borsec.
\end{abstract}

\footnotetext{
* Nicolae Muica, Geography Institute, Str. Dimitrie Racovita 12, 70307 Bucuresti 20, Romania

** David Turnock, Geography Department, The University, Leicester LE1 7RH, United Kingdom
}

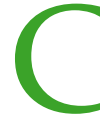
orbu is a Transylvanian village in the Eastern Carpathians, located close to the border with Moldavia at an altitude of some $700 \mathrm{~m}$ in the Bistricioara valley (a tributary of the Bistrita). Although it lies on the main road connecting Cluj-Napoca with Iasi (via Reghin, Toplita and Targu Neamt), the locality rather isolated by the lack of direct links northwards towards Bistrita and Vatra Dornei. Moreover in this area lies on Transylvania's frontier with Moldavia - historically separating the former Habsburg and Ottoman Empires - with much evidence of military activity during the First World War when the Central Powers were trying to break through into the then Romanian kingdom. However the boundary does not follow the principal watershed lying to west, so that the partially-modernised roads into the upper Bistricioara from the Gheorgheni Depression (e.g. from Ditrau to Borsec and Tulghes negotiate high passes (at $1259 \mathrm{~m}$ and $1025 \mathrm{~m}$ respectively), as does the main road already referred to (at the Borsec/Creanga pass: $1105 \mathrm{~m}$ ) and another modernised from Gheorgheni to Piatra Neamt (Bicaz Pass: 1256m) (Pisota et al. 1976). In geological terms there a contact between the eruptive and crystalline-mesozoic rocks of the Eastern Carpathians and there is some rare vegetation on the southern flanks of the Bistrita Mountains, including the limestone massif of Pietrele Rosii (Ghinea 1998 p.3-316). But there is a tradition of unity through the Hungarian district name 'Gyergyo' (lacking an exact equivalent in Romanian) which is commonly used as a prefix to the Hungarian names for the principal settlements (Figure 1).

When Romanian administration began after the First World War the upper Bistricioara (Bilbor, Borsec, Corbu, Tulghes and the Bicaz area of Gheor- gheni) comprised the Tulghes 'plasa' (or district) within Ciuc county, while the larger depression to the west was divided between the Gheorgheni and Toplita districts (in Ciuc and Mures-Turda counties respectively). But the Tulghes district was subsequently split between these two and this arrangement persisted into the communist period when Toplita district (now labelled a 'raion') included Bilbor, Borsec, Corbu, Galautas, Sarmas and Subcetate (Pufulete \& Dumitrescu 1983); while Gheorgheni district included Ditrau, Lazarea, Remetea and Tulghes - all within the Hungarian Autonomous Region based on Targu Mures. These arrangements gave way to the present situation in 1968 when districts were eliminated and counties restored: now the entire district comprises the northernmost part of Harghita county, with a large Hungarian majority, but it also lies on the northeasterly limit of the territory where the Secui population mingled with Romanian pastoralists in the Medieval period and there is still a mixed Hungarian-Romanian population. There are Romanian majorities in Bilbor, Corbu and Tulghes in the Bistricioara Valley and in Galautas, Sarmas, Subcetate and Toplita in the Gheorgheni depression; with Hungarian majorities elsewhere.

The long-term population trend shows a transfer from rural areas to the three towns of Borsec, Gheorgheni and Toplita (Table 1). But data for 1966 and 1992 shows growth in several commune centres - Bilbor, Ditrau, Galautas, Remetea, Sarmas and Subcetate (and in these communes overall except for Subcetate). In terms of ethnic balance only the town of Toplita and the villages of Galautas and Lacu Rosu have changed from a Hungarian majority in 1966 to a Romanian majority in 1992, but the Hungarian population has declined relatively in the majority of villages (and especially in the towns), although Ditrau, Lazarea and Remetea (and the towns of Borsec and Gheorgheni) are confirmed as Hungarian bastions (Table 2). Natural increase among the Romanians has probably been greater: indeed, Table 3 shows natural decrease for 1998-2000 in all Hungarian majority areas whereas the balance is positive in all the predominantly Romanian areas except Corbu and Subcetate. But there would also appear to have been some consolidation of the Hungarian population given the absolute growth in Ditrau and Reme- 


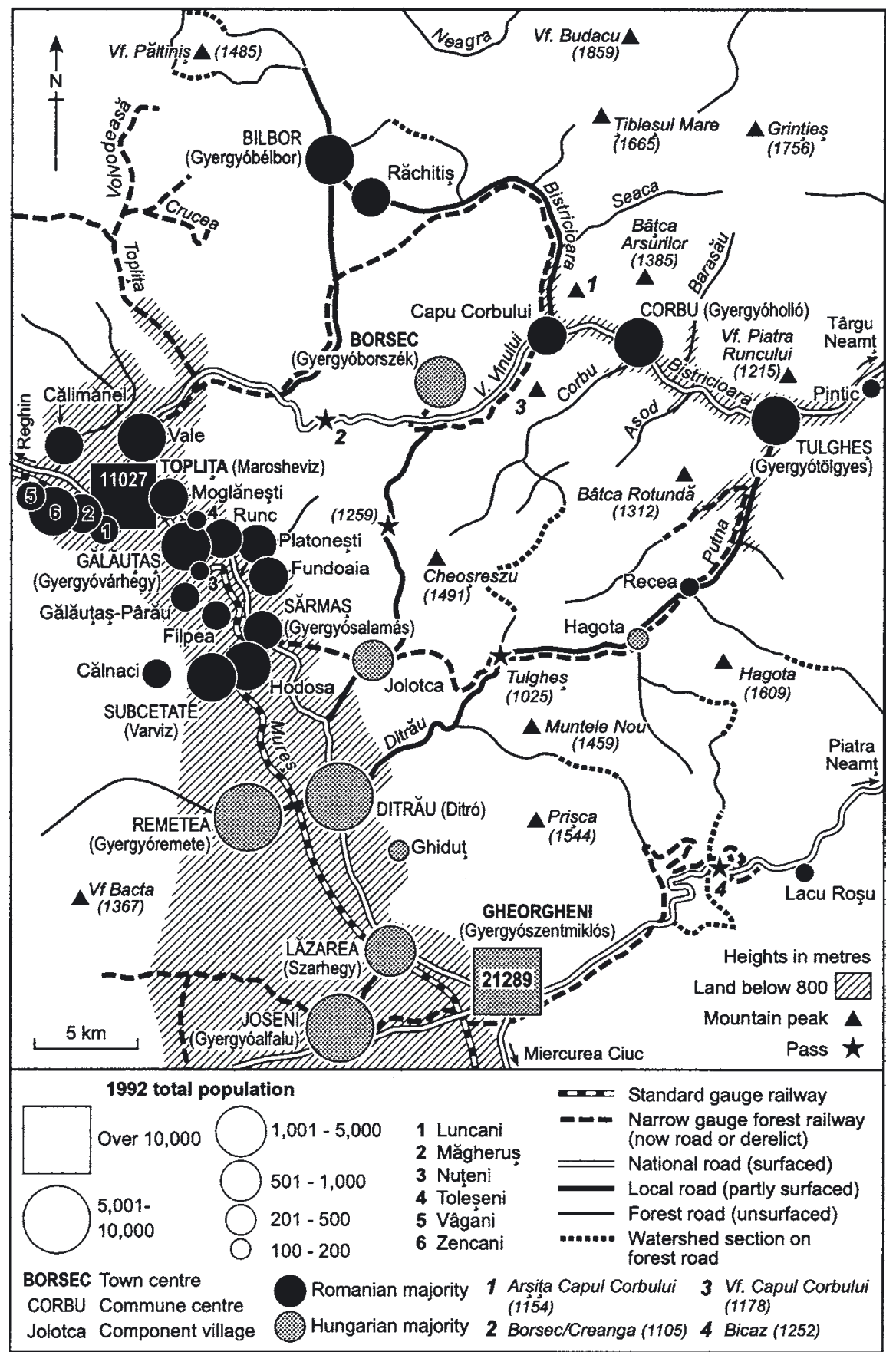

Table 1 Population trends by towns and communes 1857-1992

\begin{tabular}{|c|c|c|c|c|c|c|c|c|c|c|c|}
\hline & \multicolumn{6}{|c|}{ Population } & \multicolumn{2}{|c|}{ Households } & \multicolumn{2}{|c|}{ Romanians $^{1}$} & \multirow{2}{*}{$\begin{array}{l}\text { Area }^{2} \\
1977\end{array}$} \\
\hline & 1857 & 1880 & 1910 & 1930 & 1966 & 1992 & 1930 & 1992 & 1857 & 1992 & \\
\hline Borsec & 542 & 1416 & 1862 & 2166 & 2750 & 3074 & 1103 & 1133 & 12.4 & 19.8 & 8.75 \\
\hline Gheorgheni & 5539 & 5503 & 8905 & 10355 & 13828 & 21433 & 5376 & 7149 & 1.7 & 10.6 & 22.27 \\
\hline Toplita & 3117 & 4276 & 7388 & 8314 & 10993 & 17212 & 2075 & 5270 & 83.9 & 69.2 & 33.97 \\
\hline Bilbor & 696 & 996 & 1351 & 1670 & 2732 & 2930 & 402 & 782 & 92.4 & 97.4 & 22.73 \\
\hline Corbu & 902 & 1146 & 1396 & 1571 & 2125 & 1622 & 362 & 579 & 80.5 & 4.4 & 14.05 \\
\hline Ditrau & 4404 & 5420 & 6144 & 6785 & 6476 & 6772 & 1561 & 2270 & 6.7 & 3 & 11.45 \\
\hline Galautas & $757^{3}$ & $971^{3}$ & $1254^{3}$ & 1591 & 2509 & 2771 & 389 & 829 & 88.5 & 72.1 & 2.94 \\
\hline Lazarea & 2728 & 3216 & 4753 & 4889 & 4454 & 3727 & 1337 & 1157 & 3.1 & 1.2 & 8.09 \\
\hline Remetea & 3316 & 4252 & 6207 & 6796 & 5830 & 6582 & 2251 & 1585 & 1.0 & 0.5 & 10.60 \\
\hline Sarmas & 1109 & 1123 & 1597 & 2066 & 4026 & 4283 & 477 & 1403 & 88.5 & 77.7 & 7.01 \\
\hline Subcetate & $892^{3}$ & $1141^{3}$ & $1475^{3}$ & 2297 & 2667 & 2347 & 578 & 759 & 98.2 & 94.7 & 5.11 \\
\hline Tulghes & 1651 & 2501 & 3879 & 3883 & 4663 & 3780 & 872 & 686 & 44.2 & 64.3 & 22.67 \\
\hline Total & 25653 & 31961 & 46211 & 52383 & 63053 & 76533 & 16783 & 23602 & 30.5 & 38.0 & 169.64 \\
\hline
\end{tabular}

${ }^{1}$ Percentage of the total population: 1857 by religion and 1992 by nationality; ${ }^{2}$ thousand ha; ${ }^{3}$ Until 1930 Galautas was included in Subcetate. The Geography Institute estimated Galautas share of the 1910 population to be virtually $46 \%$ of the total andthis proportion has been applied to the 1853 and 1880 figures; Note that Joseni (shown in Figure 1) is not coverd by the statistics

Source: Census Reports (re-issued in the case of 1857 and 1880)
- Figure 1 The 'Gyergyo' region of northeastern Transylvania. Note that the essentials of the river system my be inferred from the road system and especially the highlighting of watershed sections for forest roads.

tea communes (as well as the towns) and the substantial decline in many other places. However this phenomenon needs further research in conjunction with the rural planning strategy for Harghita during the communist period. Table 3 shows a positive migration balance in terms of permanent residence (domicile) in Lazarea and Remetea (also Subcetate) during 1998-2000 which even the three towns cannot match. Migration for temporary residence is positive in Borsec and Gheorgheni and in the industrial zone of Galautas-Sarmas. However, it is interesting to see that when the census returns for 1992 are compared with the data on religion in 1857 (when the Romanians would have been Orthodox or Uniate) there is a slight tendency towards polarisation over the 135 year period and a more consistent Romanian advance in the eastern part of the region than the west (Table 1).

But while ethnic relations are an important element in the geography, with an emphasis on peaceful coexistence (with mixed communities in most villages and good neighbourly relations which extend to business partnerships), this study is motivated primarily by the data available from published field studies carried out in 1933 and 1977 which help in building a perspective extending through the last century. The Romanian author has carried out fieldwork in recent years along with the UK author who organised the 1977 project - under the auspices of British 'Geographical Field Group' (Turnock et al. 1980) - and subsequently researched the earlier programme organised by the Le Play Society (Fleure \& Pelham 1936). Pastoralism is dominant, for the upper Bistricioara is close to the limits of cultivation - with agriculture severely constrained by relief as well as climate and necessarily limited largely to maize and potatoes (the average annual temperature at Bilbor - at the head of the Bistricioara - is 4deg.C (14deg in July and -6deg in January). This typical Carpathian valley system contrasts with the extensive flatfloored depressions threaded by Mures and Olt rivers in the west of the district. And, links across to old frontier to Piatra Neamt notwithstanding, it is here where 
the principal markets and opportunities for non-agricultural employment lie; with the completion of the railway arc Brasov-Miercurea Ciuc-Toplita-ReghinTargu Mures-Turda in 1909 an important benchmark for economic diversification.

\section{Early Development Trends in the Bistricioara Valley}

Within the valley the small town of Borsec (which gained urban status in 1952) provides a local market. Indeed this famous spa town has a significant tourist profile on account of carbonaceous waters containing bicarbonate and calcium. According to tradition, the springs were discovered by a hunter in the fifteenth century, but it was only after a military presence was established in 1762 that serious investigations led to the validation of the curative properties in Vienna in 1777 (Kurz 1844). Although visitors made the journey from the beginning of the nineteenth century the principal activity was the distribution of the mineral water from 1805 when a 28 year lease was taken by an engineer from Vienna (it was fortunate that a local silica deposit facilitated local manufacture of bottles!). The first balneary establishment was instigated by Dr Neustadter in 1873 (Calimanascu \& Zaharia 1981) when Borsec water won a number of international distinctions and from 1889 the practice of taking a hot (mud) bath ('bai de namol'/'bai clocotitoare') (Szonyi 1958) in wooden tubs - with local peat and lignite as convenient fuels - was recommended as part of the cure for a number of ailments. But transport was difficult with patients needing a 'diligenta' all the way from Reghin (where the railway arrived from Targu Mures in 1886) until 1909 when the coach journey was limited to the section from Toplita only - though other railheads would have been available at Piatra Neamt (from 1885), Miercurea Ciuc (from 1897) and Gheorgheni (1907).

Meanwhile springs at Bilbor assumed a local and seasonal importance. And the commercial economy also featured the logging industry which in terms of transport was initially an adjunct of the rafting system on the Bistrita (Simionescu 1925). But after the railway was built through the Gheorgheni Depression a number of forest railways appeared, including one from Toplita to Bilbor and Corbu (eventually reaching Borsec to allow easier distribution of the mineral water) which was part of an
Table 2 Population in the towns, communes and principal villages 1966/92

\begin{tabular}{|c|c|c|c|c|c|c|c|c|c|c|c|}
\hline \multirow{2}{*}{\begin{tabular}{|l|} 
Town / \\
Commune and \\
Village
\end{tabular}} & \multicolumn{4}{|c|}{1966} & \multicolumn{4}{|c|}{1992} & \multirow{2}{*}{$\begin{array}{c}\text { Percentage } \\
\text { change } \\
1992\end{array}$} & \multicolumn{2}{|c|}{1966 - Ratio囚 } \\
\hline & Total & A & B & c & Total & A & B & C & & 1966 & 1992 \\
\hline BORSEC & 2750 & 364 & 2375 & 11 & 3074 & 609 & 2451 & 14 & +11.8 & 6.50 & 4.00 \\
\hline GHEORGHENI & 13828 & 956 & 12765 & 107 & 21433 & 2265 & 18946 & 222 & +55.0 & 13.40 & 8.40 \\
\hline Gheorgheni & 13249 & 762 & 12381 & 106 & 21289 & 2169 & 18888 & 222 & +60.7 & 16.20 & 8.80 \\
\hline Lacu Rosu & 340 & 124 & 215 & 1 & 101 & 81 & 20 & & -70.3 & 1.70 & .25 \\
\hline TOPLITA & 10993 & 6533 & 4348 & 112 & 17212 & 11903 & 5038 & 271 & +56.6 & .67 & .42 \\
\hline Toplita & 4129 & 1680 & 2365 & 84 & 11027 & 6953 & 3876 & 198 & +167.1 & 1.40 & .56 \\
\hline Calimanel & 1009 & 938 & 69 & 2 & 989 & 953 & 36 & & -2.0 & .07 & .04 \\
\hline Luncani & 295 & 287 & 6 & 2 & 314 & 274 & 17 & 23 & +6.4 & .02 & .06 \\
\hline Magherus & 875 & 486 & 388 & 1 & 766 & 431 & 321 & 14 & -12.5 & .80 & .74 \\
\hline Moglanesti & 811 & 555 & 252 & 4 & 751 & 550 & 194 & 7 & -7.4 & .45 & .35 \\
\hline Vale & 2052 & 1573 & 472 & 7 & 2033 & 1741 & 281 & 11 & -0.9 & .30 & .16 \\
\hline Vagani & 281 & 252 & 22 & 7 & 249 & 237 & 12 & & -11.4 & .09 & .05 \\
\hline Zencani & 1387 & 754 & 621 & 12 & 1001 & 755 & 228 & 18 & -27.8 & .82 & .75 \\
\hline BILBOR & 2732 & 2575 & 153 & 4 & 2930 & 2853 & 77 & & +7.2 & .06 & .03 \\
\hline Bilbor & 2210 & 2064 & 143 & 3 & 2395 & 2324 & 71 & & +8.4 & .07 & .03 \\
\hline Rachitis & 522 & 511 & 10 & 1 & 535 & 529 & 6 & & +2.5 & .02 & .01 \\
\hline CORBU & 2125 & 1683 & 440 & 2 & 1622 & 1369 & 220 & 33 & -23.7 & .26 & .16 \\
\hline Corbu & 1260 & 1037 & 222 & 1 & 1068 & 911 & 138 & 19 & -15.2 & .21 & .15 \\
\hline Capu Corbului & 865 & 646 & 218 & 1 & 554 & 458 & 82 & 14 & -36.0 & .34 & .18 \\
\hline DITRAU & 6476 & 31 & 6396 & 49 & 6772 & 12 & 6589 & 171 & +4.6 & 206 & 549 \\
\hline Ditrau & 5766 & 23 & 5694 & 49 & 6078 & 12 & 5895 & 171 & +5.4 & 248 & 491 \\
\hline Jolotca & 710 & 8 & 702 & & 694 & & 694 & & -2.3 & 88 & 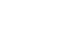 \\
\hline GALAUTAS & 2509 & 1557 & 939 & 13 & 2771 & 1998 & 742 & 31 & +10.0 & .60 & .37 \\
\hline Galautas & 1517 & 604 & 902 & 11 & 2012 & 1266 & 715 & 31 & +32.6 & 1.5 & .56 \\
\hline Galautas-Parau & 402 & 397 & 3 & 2 & 400 & 393 & 7 & & -0.5 & .01 & .02 \\
\hline Nuteni & 92 & 92 & . & . & 118 & 112 & 6 & & +28.3 & & .05 \\
\hline Toleseni & 126 & 92 & 32 & 2 & 104 & 90 & 14 & & -17.5 & .35 & .16 \\
\hline LAZAREA & 4454 & 35 & 4366 & 53 & 3727 & 46 & 3636 & 45 & -16.3 & 125 & 79 \\
\hline Lazarea & 4176 & 29 & 4125 & 22 & 3564 & 43 & 3476 & 45 & -14.7 & 142 & 80 \\
\hline Ghidut & 278 & 6 & 241 & 31 & 163 & 3 & 160 & & -41.4 & 40 & 53 \\
\hline REMETEA & 5830 & 31 & 5751 & 48 & 6582 & 35 & 6449 & 98 & +12.9 & 186 & 184 \\
\hline Remetea & 4029 & 29 & 3961 & 39 & 6498 & 35 & 6365 & 98 & +61.3 & 137 & 188 \\
\hline SARMAS & 4026 & 2883 & 1138 & 5 & 4283 & 3327 & 945 & 11 & +6.4 & .39 & .28 \\
\hline Sarmas & 602 & 448 & 153 & 1 & 777 & 649 & 128 & & +29.1 & .34 & .20 \\
\hline Fundoaia & 729 & 700 & 29 & 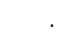 & 658 & 627 & 31 & & -9.7 & .04 & .05 \\
\hline Hodosa & 1584 & 771 & 809 & 4 & 1592 & 998 & 592 & 2 & +0.5 & 1.05 & .59 \\
\hline Platonesti & 489 & 487 & 2 & & 556 & 549 & 7 & . & +13.7 & 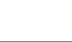 & .01 \\
\hline Runc & 672 & 477 & 195 & . & 700 & 504 & 187 & 9 & +4.2 & 0.4 & 0.4 \\
\hline SUBCETATE & 2667 & 2522 & 144 & 1 & 2347 & 2222 & 115 & 10 & -12.0 & .06 & .05 \\
\hline Subcetate & 1350 & 1253 & 96 & 1 & 1518 & 1444 & 72 & 2 & +12.4 & .08 & .05 \\
\hline Calnaci & 530 & 530 & & & 342 & 341 & 1 & & -35.5 & & 凶 \\
\hline Filpea & 700 & 553 & 47 & & 429 & 379 & 42 & 8 & -38.7 & .08 & .11 \\
\hline TULGHES & 4663 & 2530 & 2104 & 29 & 3780 & 2432 & 1318 & 30 & -18.9 & .83 & .54 \\
\hline Tulghes & 3987 & 2238 & 1720 & 29 & 3319 & 2150 & 1139 & 30 & -16.8 & .77 & .53 \\
\hline Hagota & 323 & 41 & 282 & & 175 & 27 & 148 & & -45.8 & 6.9 & 5.5 \\
\hline Pintic & 151 & 129 & 22 & & 123 & 123 & & & -18.5 & .17 & $\nabla$ \\
\hline Recea & 202 & 122 & 80 & & 163 & 132 & 31 & & -19.3 & .66 & .23 \\
\hline TOTAL & \begin{tabular}{|l|}
63053 \\
\end{tabular} & 21700 & 40919 & 434 & 76533 & 29071 & 46526 & 936 & +21.4 & 1.9 & 1.6 \\
\hline
\end{tabular}

A - Romanians; B - Hungarians; C - Others; $\otimes$ Hungarians per one Romanian, $₫$ bellow 0.01; $\nabla$ ratio not available because only one group present. Source: Census Reports

extensive network in the Toplita basin while others ran from Gheorgheni to the Bicaz Pass and from Sarmas to Tulghes, all requiring complex engineering to gain height and access the most valuable stands of resinous timber. The first water-powered sawmill ('joagar') in Tulghes is dated 1875, but local pro- cessing was overtaken by centralised facilities in the communist period when the mills at Piatra Neamt were complemented by a new complex at Galautas. Communism did boost Borsec's importance as a spa, with capacity raised from 3,500 to 14,000 visitors after nationalisation when administration passed to the 


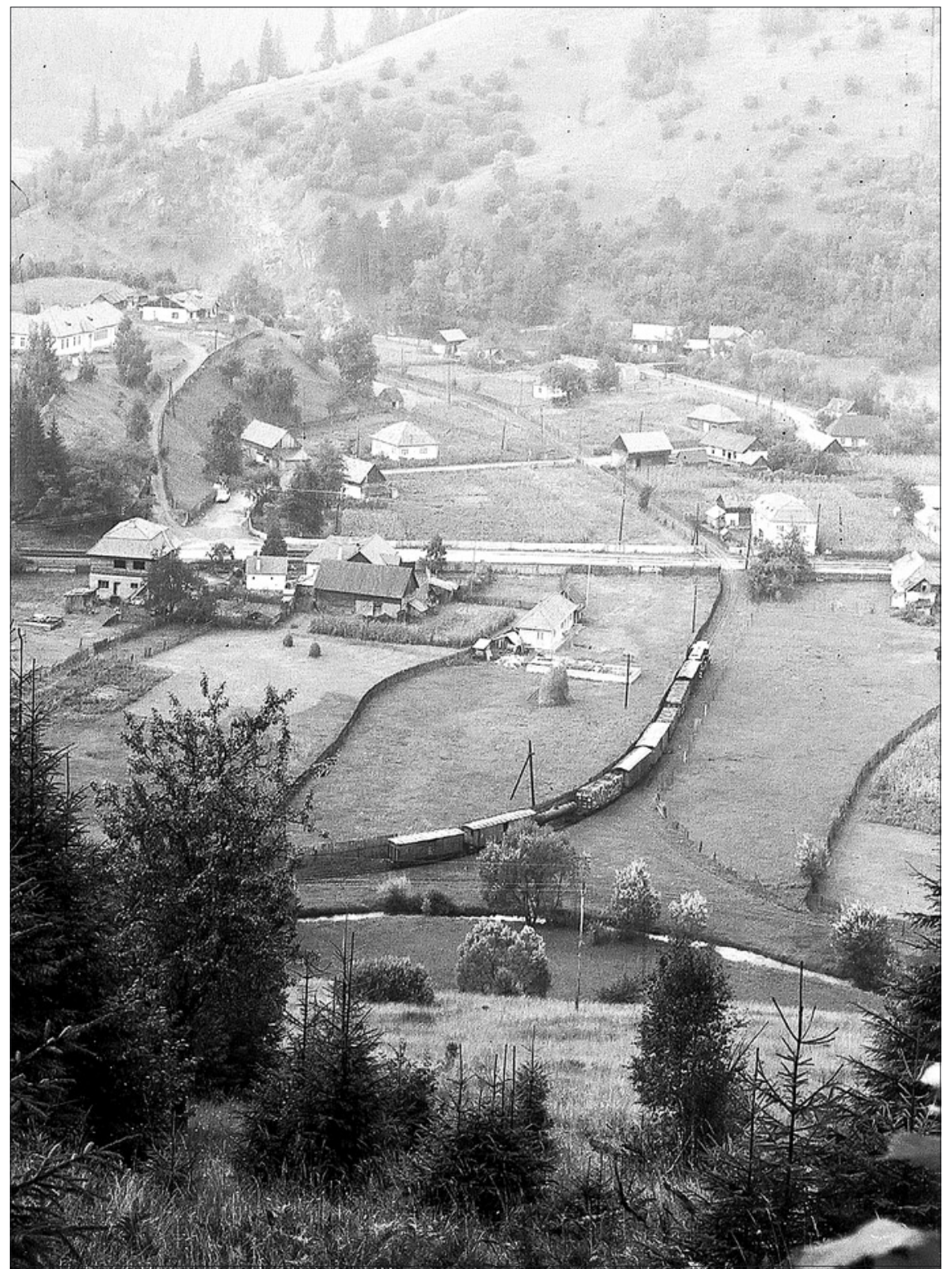

Plate 1 A trainload of mineral water passes through Capu Corbului (1977)

Ministry of Health and the trade unions (Cianga 1998). Mineral water bottling was placed in the hands of Apemin in 1952 and production reached 50mln.1 in 1976 - after the award of the 'Regina Apelor Minerale' diploma in 1972. The narrow gauge railway was still used for transport and many visitors were carried in an improvised railcar until buses took over (Plates 1-2). The railway survived until the revolution and - although now dismantled - the viaduct giving access to the bottling plant (built in the local travertine) still stands as the greatest man-made monument in the district. The spa generated considerable employment with further opportunities for women in a small clothing factory.

\section{The Commune of Corbu Through the Twentieth Century}

As an essentially self-sufficient community before the late 19th century, the subsistence farming community of Corbu was supported by local water mill processing cereals, timber and woollen blankets; although commune boundaries were disputed with the village of Jolotca in Ditrau commune and only after the Second World War did Corbu gain full control of the Corbu valley catchment. However, the Le Play members saw Corbu approaching "a crisis in its history [for] the old economic self-sufficiency is being undermined by the insidious influence of the journeyman and the cheapness of the new wares that he is introducing will tend to increase the amount of leisure that the peasant already enjoys" (Fleure \& Pelham 1933 p.74). Given the constraints on massive expansion of farm output for export and on emigration of the surplus population, the growing Borsec spa was seen as an agricultural market "in spite of a toilsome journey of several miles, for its greater altitude and more exposed position make farming even more precarious than it is at Corbu" (Ibid p.74). There was however some confidence about increasing crop yields gradually and securing a measure of industrial development.

Thetransition was accomplished under communism by permanent migration to growing industrial centres and also by commuting by bus to Borsec. Meanwhile local manufacturing was eliminated: the loom disappeared from virtually all the farms, while the wool-combing shed closed in 1949 as did the sawmill in the upper valley in 1957 (although the fulling mill operated until the revolution and domestic weaving continued in some homes into the early 1990s). Electricity arrived around 1960 and a clinic was provided also two eight-year schools, a community hall (camin), with cinema facilities and specialist shops replaced the old general store. Dress was almost entirely westernised, with traditional costume reserved (by the older people!) for the September festival. But local employment was very
Table 3 Population, natural increase and migration 1998/2000 average

\begin{tabular}{|l|r|r|r|r|r|r|r|r|r|r|}
\hline & A & \multicolumn{1}{c|}{ B } & \multicolumn{1}{c|}{ C } & D & E & F & G & H & I & J \\
\hline Borsec & 3085 & 3108 & 1594 & 51.3 & 8.9 & 12.3 & 7.8 & 9.5 & 27.1 & 17.8 \\
\hline Gheorgheni & 21175 & 21231 & 10802 & 50.9 & 9.2 & 10.2 & 6.7 & 8.8 & 21.6 & 19.0 \\
\hline Toplita & 16834 & 16770 & 8508 & 50.7 & 11.0 & 9.5 & 7.3 & 9.9 & 25.6 & 29.4 \\
\hline Bilbor & 2880 & 2900 & 1345 & 46.4 & 10.9 & 10.6 & 4.6 & 8.8 & 16.4 & 22.2 \\
\hline Corbu & 1602 & 1575 & 791 & 50.2 & 11.2 & 17.3 & 10.6 & 11.2 & 7.6 & 24.8 \\
\hline Ditrau & 6410 & 6356 & 3184 & 50.1 & 10.2 & 15.2 & 4.2 & 8.0 & 6.8 & 15.3 \\
\hline Galautas & 2896 & 2923 & 1502 & 51.4 & 10.4 & 9.7 & 7.9 & 11.0 & 35.7 & 26.6 \\
\hline Lazarea & 3684 & 3647 & 1846 & 50.6 & 10.6 & 13.8 & 10.3 & 6.5 & 5.8 & 15.9 \\
\hline Remetea & 6565 & 6471 & 3195 & 49.4 & 12.3 & 12.8 & 6.2 & 5.1 & 3.1 & 16.2 \\
\hline Sarmas & 4355 & 4326 & 2175 & 50.3 & 10.1 & 11.2 & 10.4 & 9.6 & 17.1 & 23.8 \\
\hline Subcetate & 2264 & 2260 & 1156 & 51.1 & 9.2 & 14.7 & 11.5 & 10.0 & 27.4 & 29.2 \\
\hline Tulghes & 3437 & 3467 & 1675 & 48.3 & 10.9 & 13.6 & 8.6 & 11.0 & 33.5 & 24.7 \\
\hline Total & 75187 & 75034 & 37773 & 50.3 & 10.3 & 11.4 & 7.2 & 8.9 & 20.1 & 21.9 \\
\hline
\end{tabular}

A Domiciled Population; B Resident Population; C Female Resident Population; D Female percentage; E Births*; F Deaths*; G In-Migration (Domiciled Population)+; H Out-Migration (Ditto)+; I In-Migration (Resident Population)*; J Out-Migration (Ditto)*; * Rates calculated per thousand of the resident population. + Ditto domiciled population.

Source: National Commission for Statistics, Miercurea Ciuc. 
limited to a handful of jobs in administration and services apart from agriculture, shepherding and forestry and so, while families had to depend on some form of non-farm income (since farm size in 1977 was little altered from the 1933 situation), work had to be found for the most part outside the commune, with commuting facilitated by buses along the main (also betweem Tulghes and Ditrau).

\section{Agriculture}

Settlement extends in a loose linear band along the valley for some five kilometres, with some growth in tributary valleys also - especially the Corbu on the right side and Barasau on the left. Although there is a better basis for agriculture than in highest settlements like Bilbor and Borsec, the conditions are still difficult. Summer is the wettest time of year and the thunderstorms that persist through July and August limit the ripening period for grain. Winter brings quite heavy snowfall and also bitter cold, with mean monthly temperatures below freezing for four to five months. River discharge is therefore low in January but highest in April, coinciding with the spring melt which is prolonged into May and June. Yet the community has always been based primarily on agriculture and traditionally the 400ha of arable land (five percent of the total area of the commune in 1933) has been owned by the Hungarian and Romanian peasants while the state has owned the forests $(58 \%$ of the total area) and the commune the remainder (small areas of forest along with hay meadows and summer pastures). The Roma - comprising a small group present since the 1930s at least - have no land apart from vegetable gardens and hence each man is "compelled to seek a livelihood by trading unless he be either

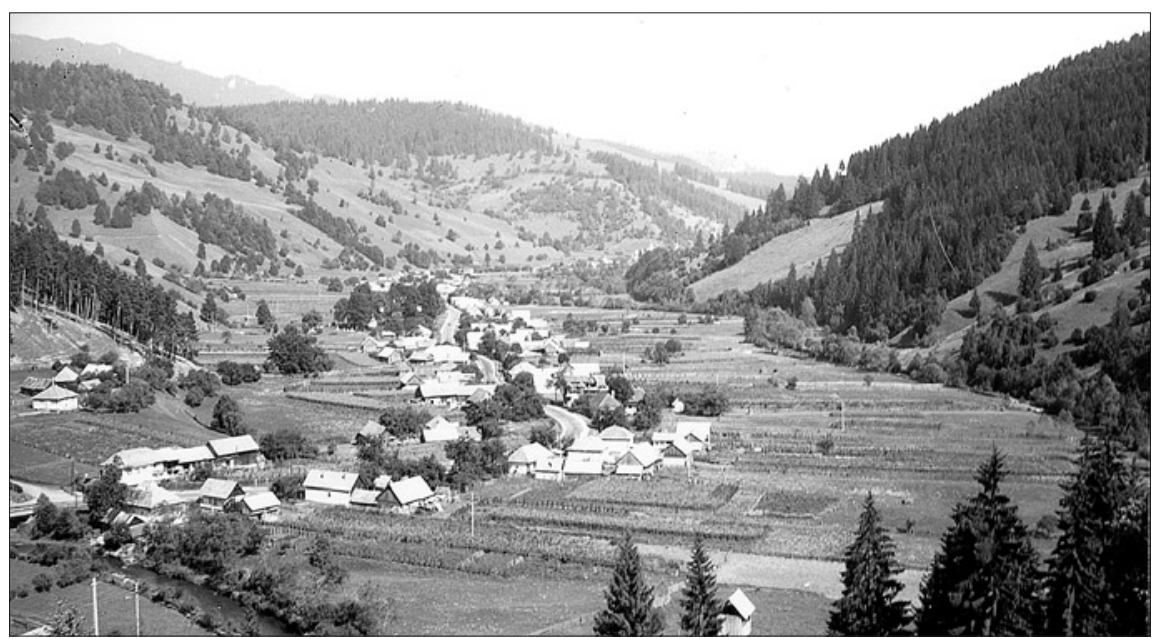

Plate 3 A view looking south from the porphyry spur along the alluvial plain from

Stramtura towards the centre of the commune. smith or musician, following the traditional pursuits of his forbears" (Fleure \& Pelham 1933 p.66). Yet, because they neither own nor work the land the Roma "are frequently castigated as indolent by the farming community" (Turnock et al. 1980 p.93).

The main valley is wide enough to provide a substantial alluvial plain consisting of level, potentially arable land - apart from alluvial fans precipitated by landslips caused by rain and snow melt - to complement the grazings available on the partially deforested crystalline schistose and gneissic slopes below the forested massifs (rising to 1,500m) with only limited clearings used for grazing on a transhumance basis. Occasionally the more gentle slopes allow limited cultivation while occasional agroterraces point to some greater initiatives in the past. But the most curious feature is an outcrop of porphyry which has evidently been breached by the Bistricioara to produce a pronounced narrowing of

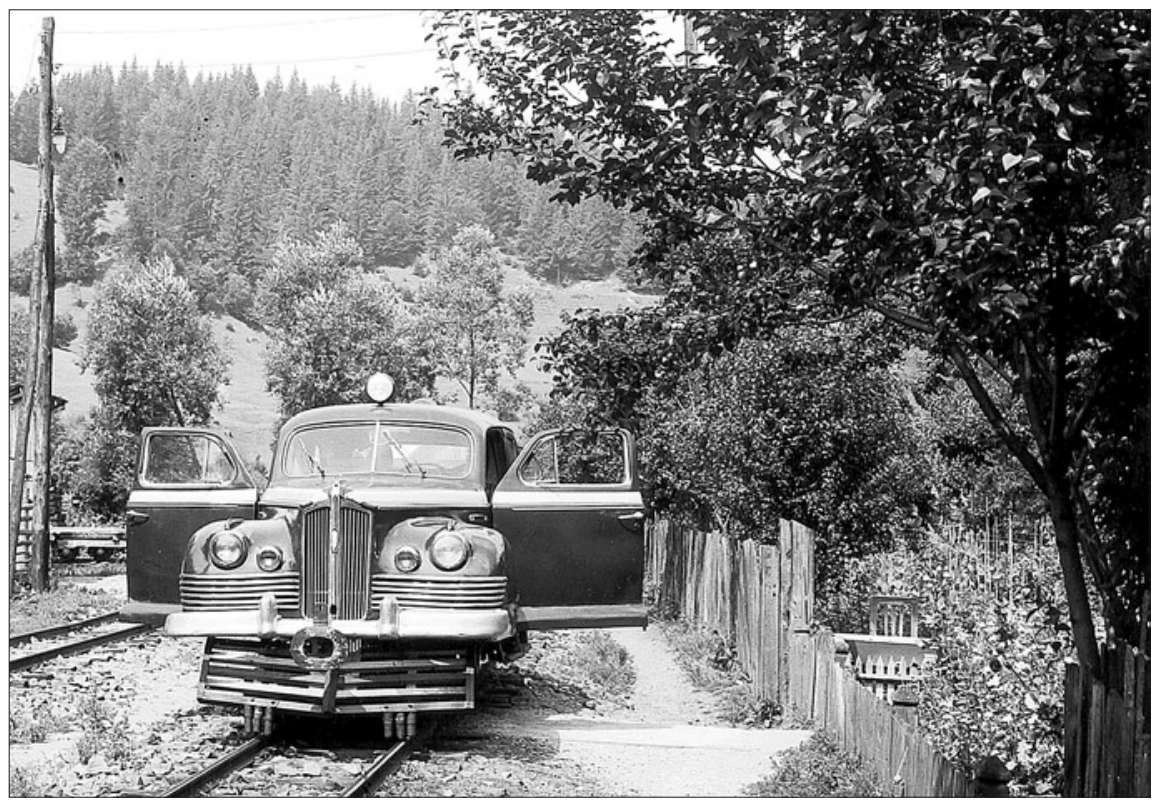

Plate 2 A car converted for use on the railway for management and VIP use (1977) marries he can claim his portion of land while on the death of the father all the land is subject to sub-division among sons and daughters on equal terms. However, while there are commuters who live in the village and farm in their spare time, "in effect the process of subdivision is now practically halted as so few sons and daughters wish to remain in the village and prefer instead to sell their portion of land to raise money for their new lives in the town" (Turnock et al. 1980 p.89). Nevertheless the heritage of several generations of subdivision and fragmentation remains. 


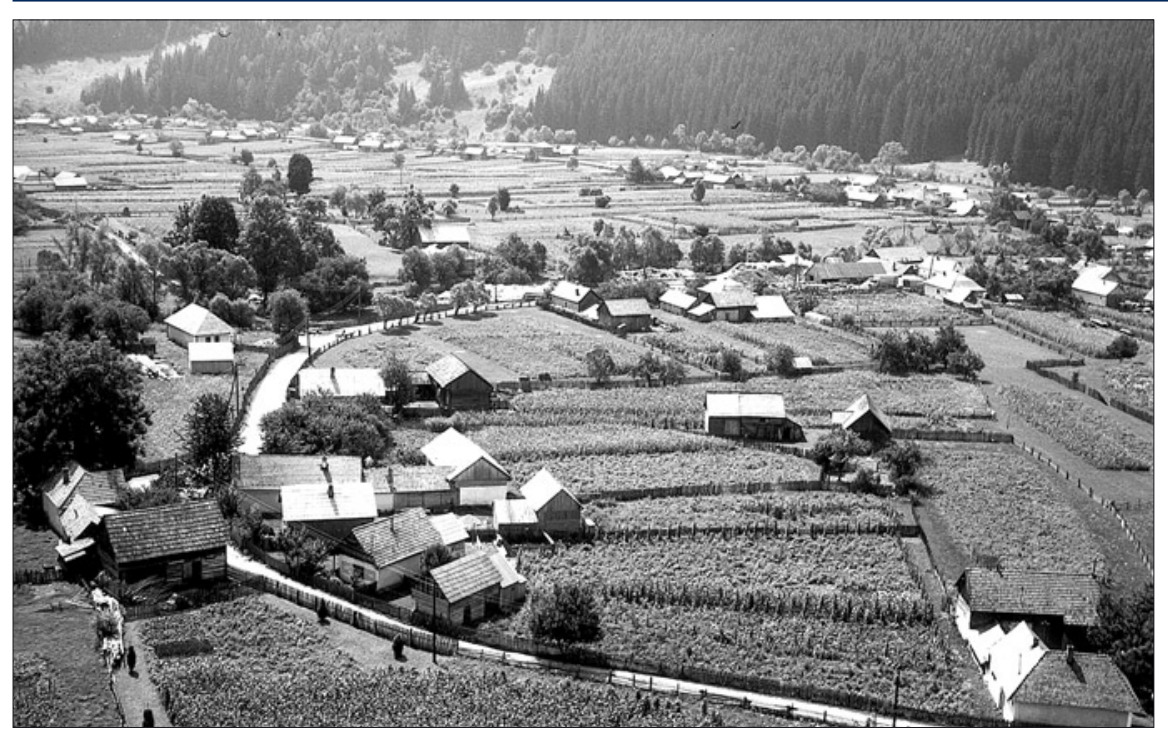

Plate 4 The small nucleus of settlement where the Barasau stream enters the main valley of the Bistricioara

The arable land is now estimated at 121ha compared with 1,245ha for hayfields and 4,199ha for grazing. Maize was the leading crop in 1933 (sown in May and harvested in September-October) but reference was also made to potatoes, hemp, flax and lucerne, along with patches of rye, sunflowers and vegetables and the occasional orchard (Figure 2). These crops were raised on the drier ground, including the fan at the mouth of the Barasau. The hayfields on damper ground play a crucial role and it is important to take a second cutting of (called 'otava'). Hay is also taken on the steep, deforested slopes above the village from July to September, working progressively up the hillsides to the higher meadows. During this period of maximum activity small cabins situated at the remoter meadows can save valuable time that would otherwise be lost in returning home each day (Plates 5-6). The land use pattern in 1977 was much simpler: hemp, lucerne, oats and rye were no longer grown but there were poppies intersown within much of the potato crop. The maize area was reduced while potatoes and hay were more important and fruit trees (apples and plums) marginally more so. There was also some evidence - through indistinct crop boundaries - of "a decline in the management of land use, possibly reflecting inadequate resources of family labour with which to run the farm" (Turnock et al. 1980 p.89). While wheat, rye and barley are now finished at Corbu, judging by survey in 1994 - cereals can now be brought in from Moldavia - there is still a greater amount of cropping than at Bilbor where only potatoes can be grown. Statistics for 2000 specify 80ha of potatoes, 20ha of maize and six of vegetables.
The official statistics for 2000 also point to 3,420 sheep and 967 head of cattle plus pigs and poultry. Production is quoted at $90 \mathrm{t}$ of meat, 1,7501 of cowsmilk, $8,000 \mathrm{~kg}$ of wool and almost a quarter of a million eggs. Livestock numbers have decreased sharply since the communist period, represented by the data for 1986 in Table 4. Prices are not sufficiently attractive to justify the purchase of feedstuffs and livestock reflect the local fodder supply and the labour available. However, among the areas listed (which excludes Gheorgheni and Lazarea) Corbu had the highest stocking rate per household after
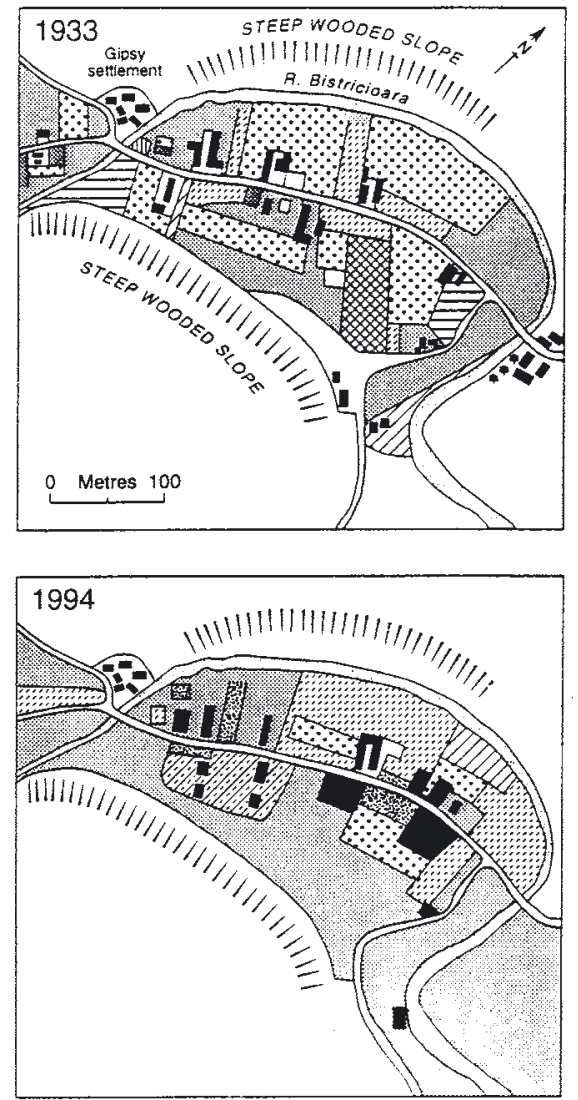

Bilbor and Tulghes. Traditional management practices continue. After housing in sheds during the winter the sheep go to a summer grazing ('stana') during late April/early May to October in the care of shepherds paid by the commune from the levies charged on each animal. In 1977 the grazings were open from May 1st to October 1st - and the 4,000ha of common pasture were supervised by a county institute with representatives in each commune - with commune committees to set agistment fees according to the maintenance work required. Nine communal 'stane' were operating in Corbu in 1977 - each with 4-5 shepherds looking after some 400 sheep (plus a few cattle and pigs). Dry stock use separate stations where they remain for a longer period of up to 10 days in the autumn. Under the direction of the head shepherd ('baciu') and milking is done three times daily to yield 100-300gr/ewe, followed by cheesemaking - for general sale to pay the shepherds, although each farm sending sheep is entitled to $8 \mathrm{~kg}$ of cheese per ewe per season. Life at the stana changes little: "apart from the intrusion of enamel and aluminium tableware among traditional wooden utensils, the most obvious concession to the $1970 \mathrm{~s}$ is the transistor radio" (Turnock et al. 1980 p.91).

After the animals return some sheep may stay out to graze on maize stubble
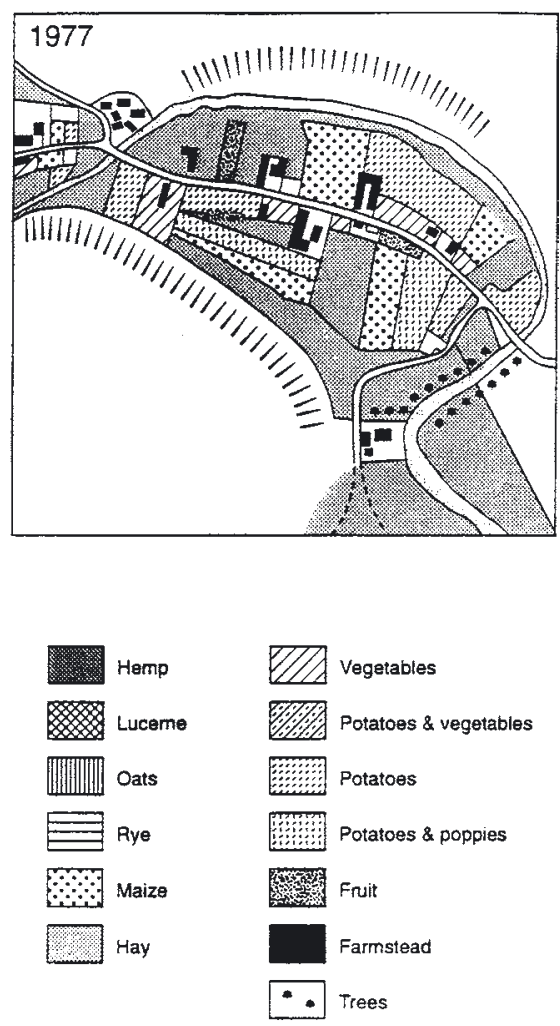

- Figure 2 Land use in the Stramtura area of Corbu 1933, 1977 and 1994 
until Christmas while surplus animals are disposed of at the autumn fairs in Toplita or Tulghes (with some export to the Czech Republic and Italy). "As spring is both late and short and the transition into winter equally abrupt, there is no grazing in the hay meadows in spring or autumn, though there is abundant visual evidence of small collecting pens for sheep which traditionally were kept on the remoter hay meadows for at least part of the winter and fed on conserved hay" (Turnock et al. 1980 p.89). Fresh milk now constitutes a major commercial activity and cattle and sheep were of roughly equal importance in 1977 . The total cattle stock was c.2000 in 1977 (double the figure today): family herds varied from one or two animals to 15 and handmilking was universal. Production is greatest in spring when the grassland is

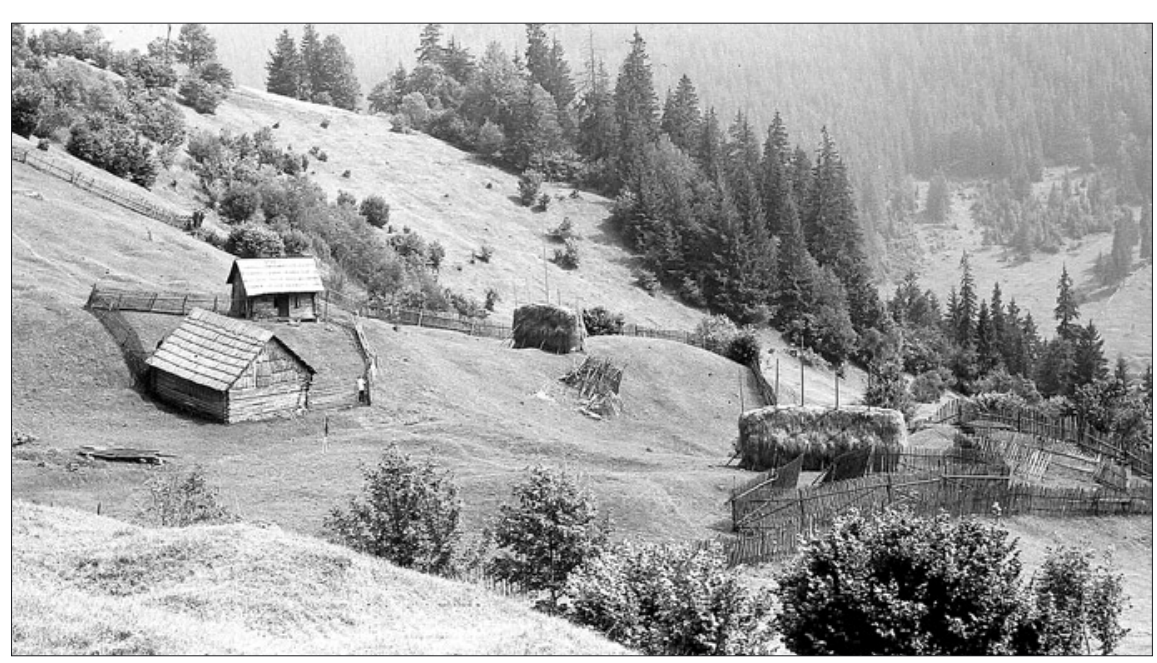

- Plate 6 The higher slopes show mixed land use (forest and pastoralism) according to slope and aspect. Stock may be kept in small sheds and enclosures - and farmers may stay overnight during the haymaking season

at its best. Milk is taken daily in churns from collecting centres in the village to the Remetea processing factory for the manufacture of cheese and milk powder. Cheese is also made locally from the milk of some 5,000 sheep; but fixed quantities of milk per ewe were also delivered to state collecting centres and wool also attracted rewarding prices (better than today). Stock prices are now low and disposal is not always possible, for the area does not have the advantage of competition among local processors. Horses continue to be important given the difficulty in using tractors (which can however be hired for spring ploughing from machine stations in neighbouring communes - but not in Corbu itself).

\section{Business}

Handicrafts have involved primarily textiles based on local wool, flax and hemp,

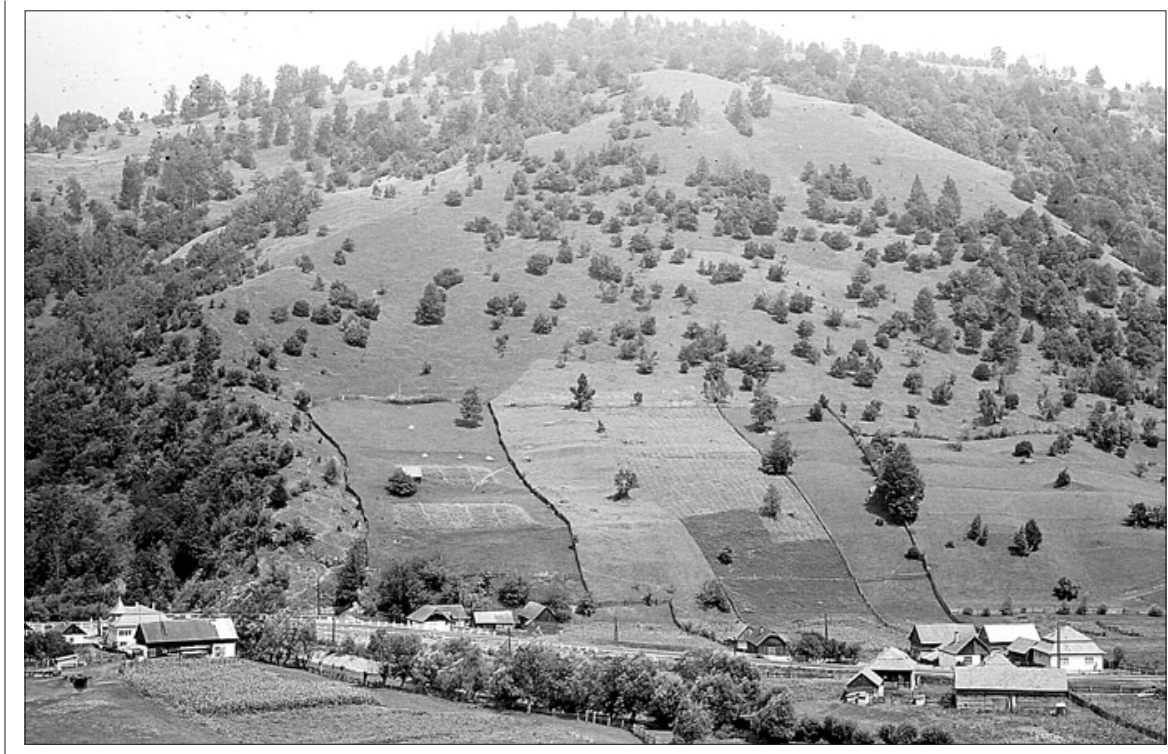

Plate 5 The contact between the alluvial plain and the valley side in Capul Corbului where gentler slopes permit some cultivation of potatoes, vegetables and maize in small fenced enclosures. Steeper slopes are forested or used for grazing and haymaking although imported cotton yarn gradually replaced linen for some of the lighter, summer garments. Most dyestuffs were obtained from local plants e.g. red dye

Table 4 Livestock

\begin{tabular}{|l|r|r|r|r|r|r|r|r|}
\hline \multirow{2}{*}{$\begin{array}{l}\text { Town / } \\
\text { Commune }\end{array}$} & \multicolumn{4}{|c|}{ Livestock Units $^{\circledR}$} & \multicolumn{4}{|c|}{ Units per Household } \\
\cline { 2 - 9 } & \multicolumn{1}{|c|}{1986} & 1990 & $1993-1995$ & $1999-2000$ & 1986 & 1990 & $1993-1995$ & $1999-2000$ \\
\hline Borsec & 517.3 & 456.8 & 396.2 & 272.4 & 0.46 & 0.40 & 0.35 & 024 \\
\hline Toplita & 5609.3 & 3420.2 & 2868.9 & 2038.8 & 1.06 & 0.65 & 0.54 & 0.39 \\
\hline Bilbor & 3553.2 & 3210.3 & 3242.9 & 2950.1 & 4.54 & 4.11 & 4.15 & 3.77 \\
\hline Corbu & 2110.7 & 1995.9 & 1800.3 & 1474.8 & 3.65 & 3.45 & 3.11 & 2.55 \\
\hline Ditrau & 5221.8 & 4961.4 & 3753.4 & 2369.0 & 2.30 & 2.19 & 1.65 & 1.04 \\
\hline Galautas & 1042.4 & 959.4 & 1154.1 & 559.9 & 1.26 & 1.16 & 1.39 & 0.68 \\
\hline Remetea & 5415.4 & 3836.0 & 3535.6 & 2383.8 & 3.42 & 2.42 & 2.23 & 1.50 \\
\hline Sarmas & 2848.0 & 2714.9 & 2401.1 & 1350.9 & 2.03 & 1.94 & 1.71 & 0.96 \\
\hline Subcetate & 2215.1 & 2189.1 & 2149.9 & 1366.9 & 2.92 & 2.88 & 2.83 & 1.80 \\
\hline Tulghes & 3314.9 & 3093.4 & 2284.4 & 1922.6 & 4.83 & 4.51 & 3.33 & 2.80 \\
\hline Total & 31848.1 & 26837.4 & 23686.8 & 16689.2 & 2.08 & 1.75 & 1.55 & 1.09 \\
\hline
\end{tabular}

ه reckoning 0.84 units for a cow; 0.20 for a pig; 0.14 for a sheep and 0.05 for a head of poultry. Note the variations in the rate of declined in the four categories during the period: cattle by $50.9 \%$, pigs $56.8 \%$, sheep $60.3 \%$ and poultry $30.2 \%$. There is no data for Gheorgheni and Lazarea.

Source: National Commission for Statistics, Miercurea Ciuc. from wild crab apple leaves, yellow from osier, black from alder or birch and fawn from walnut (the mordant used was salt colours other than black would fix themselves in wool without this treatment). However, imported dyes were coming into use even in 1933. Spinning using the distaff and weaving on the loom - along with combing, dyeing and embroidering - were all tasks performed by women, although a few men specialised in embroidering sheepskin waistcoats. The traditional laced shoe was already being replaced by imported footwear in the 1930s, while socks and stockings brought at local fairs were being preferred to the traditional method of bandaging. The Uniate priest played a key role in business, being trusted to grind maize, crush sunflower seed, saw timber and scour cloth using water power. Craftsmen in the villages then included bakers, bootmakers, chauffeurs, 


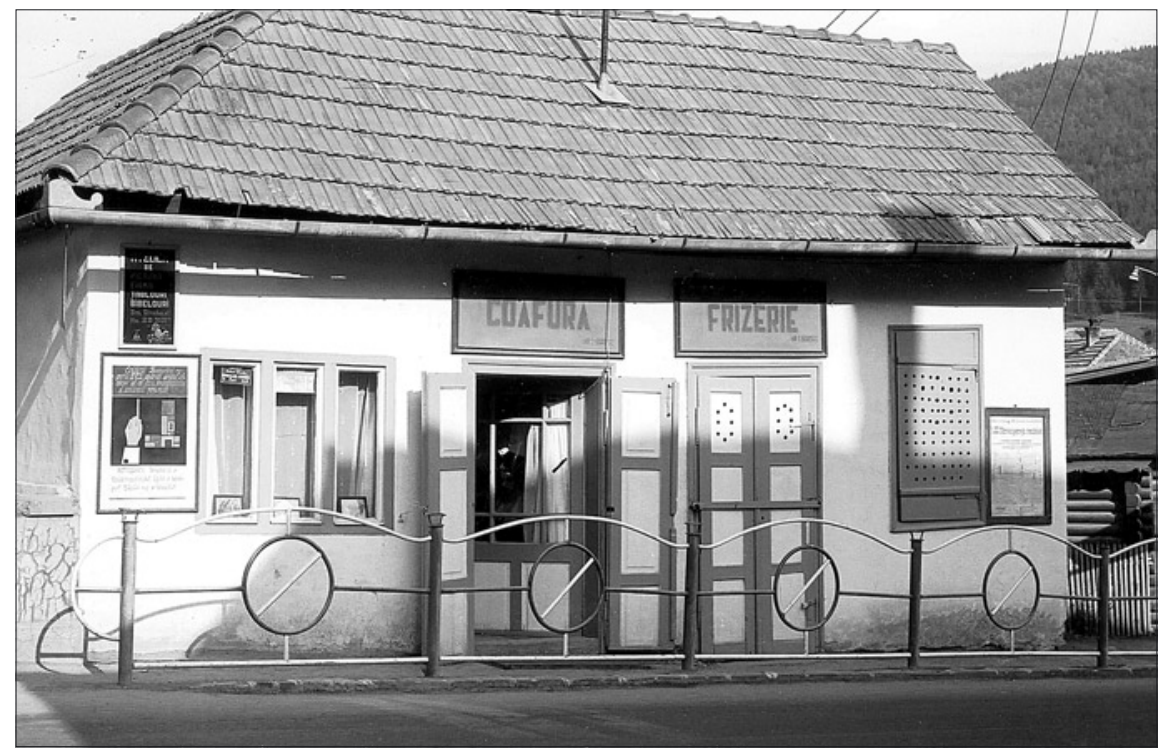

- Plate 7 Small shops in Capu Corbului

foresters, joiners and smiths. These activities have now disappeared but a private bakery is doing well using flour from Moldavia, though it was forced to close for a time when bread from the cooperative bakery in Borsec at was available at prices subsidised by the government. Originally using the derelict water-powered fulling mill ('steaza') the bakery now supplies the down-valley settlements of Grinties and Tulghes.

In 1933 each peasant was allowed a quantity of wood annually with cutting arranged with the Forestry Cooperative Society - and for every tree felled a new one was to be planted. But wooden spoons, jugs and plates made by the menfolk were being challenged by cheap imported metal goods. Today there has been restitution through onehectare woodland plots to former owners and local sawmilling has resumed with some 10 units of varying size using mainly second-hand equipment. Wood is obtained from private owners but also from the commune and from 'Romsilva' which manages the state forests. The largest unit has installed a pre1914 Austrian saw (refurbished after use by a cooperative farm in the Reghin area during the communist period) to cut thick stems into planks, while small stems are squared into beams using a new saw recently manufactured in Gheorgheni. A smaller mill produces pallets and was also barters small stems in Moldavia for cereals (with the timber source validated by the commune office). The mills use electricity and traditional water-powered installations have not been refurbished. It is unfortunate that there is no local use for sawdust which has to be burnt in pits.
Although employment in Borsec has collapsed and many people have left the area (often finding work abroad) there is little new enterprise locally and rural tourism has not been taken up despite the passing trade that the road traffic might deliver. One farmer makes brandy but in the absence of significant plum orchards he uses mainly apples and cereals (maize and rye). The brandy is strong (due to double distillation), but production is small and most is exchanged on a purely local basis. Services provide a number of jobs in health and education as well as shopping (which includes occasional markets), while the Orthodox (formerly Uniate) and Roman Catholic churches - serving Romanians and Hungarians respectively - are present in both Corbu and Capu Corbului and there is also a Baptist congregation (Plate 7). It is significant that in 1990 a secondary school ('liceu') was opened in Corbu for Romanian students in the Bistricioara valley from Bilbor and Borsec

Table 5 Employment structure 1960-1992

\begin{tabular}{|c|c|c|c|c|c|c|c|c|c|c|c|c|c|c|}
\hline & \multicolumn{4}{|c|}{1960} & \multicolumn{10}{|c|}{1992} \\
\hline & A & B & c & D & A & B & c & $c 1$ & c2 & c3 & D & d1 & d2 & d3 \\
\hline Borsec & 1228 & 425 & 10 & 793 & 1473 & 34 & 814 & 282 & 473 & 59 & 625 & 328 & 69 & 147 \\
\hline Toplita & 5115 & 2052 & 1277 & 1736 & 8171 & 356 & 5029 & 137 & 4527 & 365 & 2786 & 1079 & 267 & 783 \\
\hline Gheorgheni & 6531 & 2943 & 827 & 2761 & 10205 & 290 & 5769 & 302 & 5115 & 352 & 4146 & 1742 & 368 & 1171 \\
\hline Bilbor & 1526 & 405 & 959 & 162 & 1597 & 1044 & 236 & 5 & 219 & 12 & 317 & 101 & 52 & 113 \\
\hline Corbu & 1190 & 468 & 575 & 147 & 738 & 393 & 160 & 58 & 91 & 11 & 185 & 81 & 28 & 38 \\
\hline Ditrau & 3378 & 914 & 1916 & 548 & 2620 & 295 & 1410 & 153 & 1085 & 172 & 915 & 299 & 115 & 205 \\
\hline Galautas & 1435 & 801 & 436 & 198 & 1143 & 82 & 825 & 14 & 797 & 14 & 236 & 80 & 27 & 58 \\
\hline Lazarea & 2842 & 402 & 1986 & 454 & 1401 & 249 & 723 & 20 & 652 & 51 & 429 & 207 & 37 & 90 \\
\hline Remetea & 3332 & 495 & 2496 & 341 & 2265 & 447 & 1233 & 20 & 1061 & 152 & 585 & 227 & 62 & 101 \\
\hline Sarmas & 2265 & 858 & 1196 & 211 & 1872 & 298 & 1084 & 84 & 968 & 32 & 490 & 83 & 129 & 103 \\
\hline Subcetate & 1684 & 438 & 1071 & 175 & 1118 & 523 & 370 & 8 & 342 & 20 & 225 & 102 & 22 & 68 \\
\hline Tulghes & 2421 & 550 & 791 & 1080 & 1681 & 662 & 334 & 97 & 212 & 24 & 685 & 161 & 140 & 284 \\
\hline
\end{tabular}

A Active; B Agriculture/Fishing; C Industry \& Construction (of which: i mining and energy; $i i$ manufacturing; iii construction); D Services (of which: iv commerce and transport; $v$ research and administration; vi education-culture and health - the balance being other branches and job seekers). Source: Census Reports. number of modern apartments is minimal. However, although only a small minority of homes (less than a hundred) have a bathroom - and an inside toilet is an even greater rarity. Houses are usually set back from the road and except in the central area are usually separated from neighbours by gardens if not by arable fields and meadows. They are traditionally built of wood (though some have a coating of plaster) for although local stone is abundant the rocks nearby are very intractable and are used only for foundations. Travertine outcrops in Borsec and is relatively easy to work but it has not been used on any scale in Corbu. Roofing usually consisted in the past of shingles or larger boards (sometimes long thin planks running the whole length of the roof). "Cleanliness and simplicity are the keynotes of the domestic economy [but while] household effects are kept down to a minimum...am enormous amount of skill is lavished, especially

in the north to Tulghes in the south - and even for others further away in Ceahlau and Grinties (some stay in lodgings in Corbu during the week). Previously students had to travel to Toplita or even Odorhei for a secondary school teaching in Romanian, although Borca in the Bistrita valley was an option in the communist period. Altogether, there were 246 salaries in 2000 of which 28 were in manufacturing (outside the commune), 50 in commerce and transport and 52 in education (including 19 at the 'liceu'). Comparative profiles for 1966 and 1992 are summarised in Table 5.

\section{Houses and 'Urbanisation'}

The 580 homes in Corbu are modest yet comfortable detached houses and the 
in the case of textiles" (Turnock et al. 1933 p.66). In 1977 it was common for each household to have two houses with the older building (relatively small and simple) used as a kitchen (with a wood-burning stove - and water from a well) whereas in 1933 the kitchen was usually situated in an outhouse.

While house styles have changed there has been a "modification of traditional design [rather] than an abrupt intrusion of new styles" (Turnock et al. 1980 p.91). Since most peasant houses have a relatively short life; each cycle rebuilding or renovation brings "an inevitable compromise between traditional design and a more modern style" (Ibid). Modernisation is more evident through the use of new materials and elaboration of design than in the platform. Imported tiles have replaced shingle and a plaster/cement finish is now much more common (sometimes covering brick rather than wood). However, the rural planning ('sistematizare') of the communist could be recognised in the central area through "its more urban style of buildings and materials" (including two-storey brick houses) while the outlying parts show little change (Ibid). And because of the need to fit houses into the space available on each site, "it proved virtually impossible to define any basic patterns to the layout of house and buildings" (Ibid). There is often some decoration through the carving of the verandah balustrade and barge-boarding of the eaves, while gable ends above the level of the eaves tend to be made of vertical planks - uncoated with plaster and rarely colour-washed. There is also a tendency towards an L-shaped plan and construction of a porch. Meanwhile, the gypsy houses form a "distinctive microlandscape of small houses, built of timber, caulked with mud and roofed with shingles, boards or tarpaper, unfenced and without either farm buildings or the customary garden plot" and with decorative features conspicuously lacking (Ibid p.93). Barns are simpler and more highly standardised: usually two-storey buildings with the lower level built of planks (and the byre section finished in lath and plasterwork to give better insulation in winter) while the upper half is jettied and built of roughly-squared, horizontal timbers. On the smallest farms the barns are simply built with logs or planks and are rarely of more than one storey. Roofing styles show a mixture with tiles or asbestos beside traditional shingles and planks. Taking entire farms there will

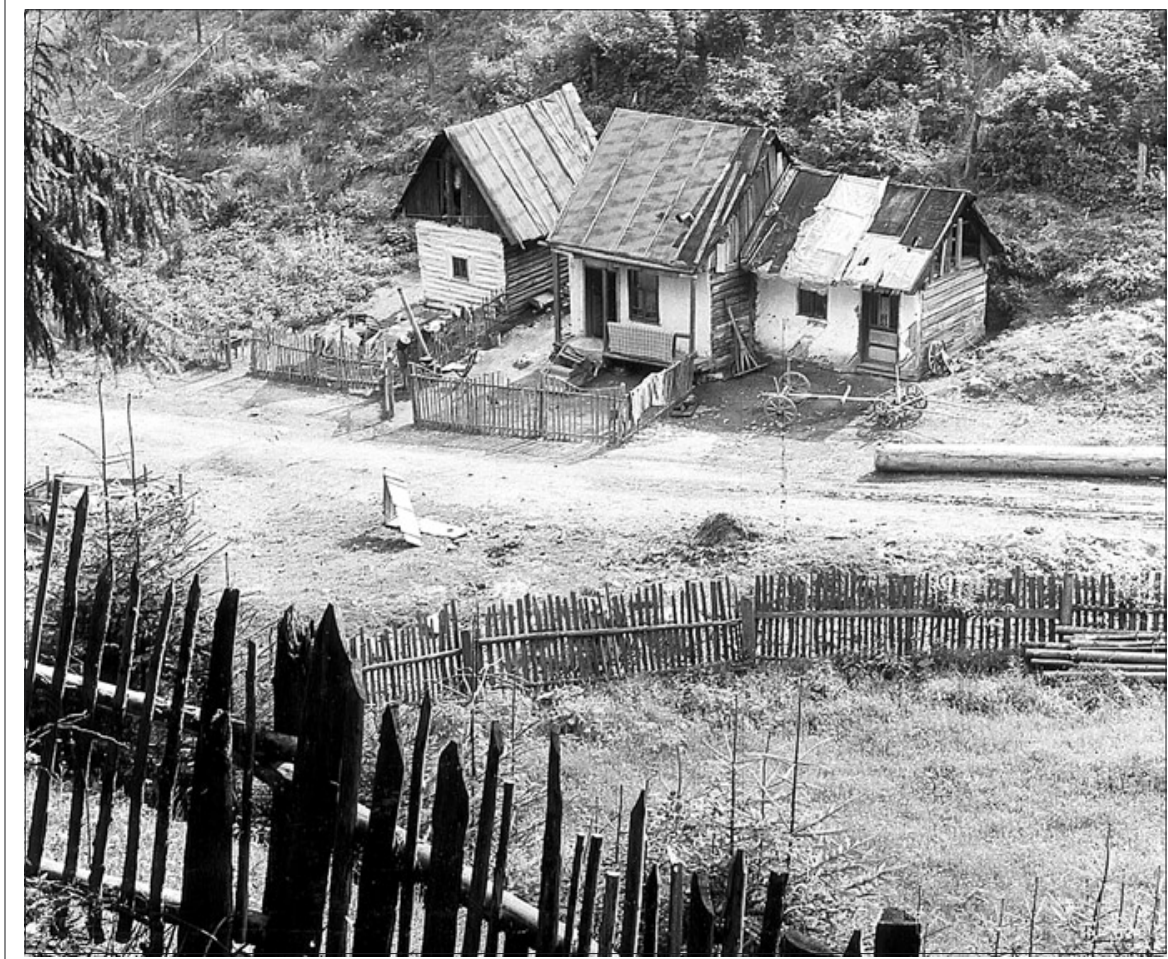

Plate 8 The modest home of a Roma family

typically be variation according to the age of the buildings.

\section{Conclusion}

This paper has presented a portrait of rural geography in a typical Carpathian valley. What makes it unusual is the possibility of drawing on two previous geographical studies which provide assessments for the inter-war and communist periods to extend the authors' impressions of the situation during the 1990s. What stands out is the stability of an economy necessarily grounded in marginal environmental conditions, as well as the cultural conditions deriving from inter-ethnic relations in a frontier region. There is also a sense of crisis as Corbu has struggled to maintain its population, although the challenges noted in 1933 did not prevent growth for another three decades and the 1977 study, while noting how the limited land resources constrained agricultural expansion, also appreciated that communist collectivisation had not disrupted traditional land management. This has reduced the degree of adjustment required since 1989 although the decline of non-agricultural employment opportunities in the district has meant further migration which aggravates a substantial natural decrease of population. There is limited scope for diversification since Borsec is the logical centre for tourism, but Corbu's centrality in the context of the Romanian community in the Bistricioara valley constitutes a cultural factor which could be promoted as the Romanian Carpathians contemplate a sustainable future in the European Community and some development of light industry could be appropriate.

\section{References}

Calimanascu S. \& Zaharia A. 1981, Mic indreptar turistic: Borsec (Bucharest: Editura Sport-Turism).

Cianga N. 1998, Turismul din Carpati Orientali: studiu de geografie umana (Cluj-Napoca: Presa Universitara Clujeana).

Fleure H.J. \& Pelham R.A. eds. 1936, Eastern Carpathian studies: Roumania (London: Le Play Society).

Ghinea D. 1996-8, Enciclopedia geografica a Romaniei (Bucharest: Editura Enciclopedica) Three volumes.

Kurz A. 1844, Borszek: Siebenburgen beruhmter Kurort (Kronstadt: Druck und Verlag von Johann Gott).

PisotaI., Iancu S. \& Buga D. 1976, Judetul Harghita (Bucharest: Editura Academiei RSR).

Pufulete R. \& Dumitrescu C. 1983, Mic indreptar turistic: Toplita (Bucharest: Editura Sport-Turism).

Simionescu G. 1925, Geografia judetului Ciuc (Bucharest: Editura Librariei H. Steinberg \& Fiul).

Szonyi B. 1958, Borszek foldrajze (Bucharest: Akademia Kiado).

Turnock D. \& Geographical Field Group Members 1980, The human geography if the Romanian Carpathians with fieldwork case studies (Nottingham: GFG). 